\title{
VARIATIONS IN HILLSLOPE RUNOFF AS DETECTED USING GEOLOGICAL STRATA COUPLED WITH VEGETATION PATTERNS- IMPLICATIONS ON SPATIALLY DISTRIBUTED DESERT RUNOFF AGRICULTURE
}

\author{
NIMROD WIELER ${ }^{1 *}$, YOAV AVNI ${ }^{2}$, MARCELO ROSENSAFT $^{2}$, \\ LINDA OLSVIG-WHITTAKER ${ }^{3}$
}

\begin{abstract}
${ }^{1}$ The Department of Geological and Environmental Sciences, Ben Gurion University of the Negev, P.O.B.653, 84105 Beer Sheva, Israel

${ }^{2}$ Geological Survey of Israel, Malkhe Yisrael 30, Jerusalem 95501, Israel

${ }^{3}$ German Protestant Institute of Archaeology in the Holy Land

Research Unit of the German Archaeological Institute, Auguste Victoria Compound P.O. B 184 63, Jerusalem 91184, Israel

*Corresponding author: Nimrod Wieler, Phone: +972 587818182; e-mail: wielern@gmail.com
\end{abstract}

Received: $30^{\text {th }}$ April 2017, Accepted: $25^{\text {th }}$ September 2017

\begin{abstract}
Sparsely vegetated bedrock slopes in deserts coincide with slope parameters, thus they have important implications on biological, chemical, hydrological and geomorphological processes. Spatial variations in these vegetation patterns, density and communities indicates on relatively humid habitats, which correspond with sinks for high runoff. Relations between the bedrock runoff generation and vegetation patterns may imply on the spatial locations of Byzantine - Early Muslim (400-1000 C.E.; 1600-1000 y BP) agriculture installations. These installations are widespread in the Negev Desert, Israel, utilized sophisticated runoff harvesting techniques by the ancient farmers. Applying a multi-disciplinary approach, we tested vegetation patterns as a precursor for runoff generation along bedrock slopes in the Negev Desert Highlands, and correlated them to the spatial distribution of the Byzantine Early Muslim runoff agriculture installations. Integrating vegetation patterns, geological substrate data and bedrock-runoff generation data on a GIS model on a large scale $\left(160 \mathrm{~km}^{2}\right)$ of the Negev Highlands yields a synthetic potential runoff map. This map is a unique new product conducted for the first time during this study. Basing on it, runoff yield can be predicted for different scales, ranging from that of a single lithology slope to that of a basin of varying lithologies. Utilizing this methodology, we show that high correlation (80\%) exists between vegetation patterns and spatially located Byzantine - Early Muslim runoff-farming installations. This correlation turns the vegetation coverage as a reliable marker for predicting runoff yield in arid bedrock slopes and imply for stable arid climate in the past 1600 years in the Negev Desert.
\end{abstract}

Keywords: Desert, Ancient runoff agriculture, Rain-bedrock-runoff relations, Vegetation patterns, Southern Levant, Climate variability, GIS 
Wieler N., Avni Y., Rosensaft M., Olsvig-Whittaker L.: Variations in hillslope runoff as detected using geological strata coupled with vegetation patterns- implications on spatially distributed desert runoff agriculture

\section{HigHLIGHTS/SIGNIFICANCE:}

The type and distribution of perennial plants along bedrock outcrops were used in this study as an essential tool for forecasting runoff generation yield in an arid environment over diverse strata.

Coupling geological strata and vegetation patterns constitute a reliable environmental marker for testing temporal and spatial variations of desert runoff agriculture.

\section{INTRODUCTION}

The present work tests the relations between hillslope vegetation patterns and hillslope runoff generated by the sequence of rock formations exposed in the Negev Highlands. We are aiming to use the vegetation cover as a precursor for runoff generation and distribution along slopes in the arid environment of the Negev Highlands. By ranking the best to the poorest runoff producer basins, we can look on the spatial relations between these basins and the distribution of the Byzantine runoff agriculture installations constructed in this region some 1600 years BP. This paper expands the synthesis framework presented by Wieler et al., (2016), for testing spatial distribution of ancient Byzantine agriculture in the Negev Desert, Israel as an indicator for late Holocene climate change in the southern Levant.

\section{Hillslope and vegetation patterns in the Negev Highlands as a tool for runoff evaluation}

Spatial variations in the distribution of vegetation patterns along arid rocky slopes was suggested to be coincide with soil rock ratio, soil properties and water distribution (Yair \& Danin, 1980; Yair \& Raz-Yassif, 2004). Thus, coupling the vegetation coverage along with the surface properties have important implications on biological, chemical, hydrological and geomorphological processes (Ackermann et al., 2013; Olswig-Whittaker et al., 1983; Hikel et al., 2012).

Plant communities in the Negev Highlands of southern Israel (Fig. 1) represent a transition from the Irano-Turanian plant chorotype to the Saharo-Arabian region (Yair \& Danin, 1980). Presence of Mesophilic plants, correlated with the Mediterranean plant geographical region indicates on relatively humid habitats, which correspond with sinks for high runoff. Yet, since the annual precipitation in the Negev highlands ranges between $90-130 \mathrm{~mm}$ it stress out the water supply and soil reservoir as a limiting factors dictating vegetation coverage along arid rocky slopes. Water availability to the plant communities along slopes was suggested by Hikel et al., (2012) to result not directly from climate conditions but also due to surface properties. Generating runoff under desert conditions was correlated to rock outcrops acting as almost impermeable surfaces (Evenari et al., 1982; Yair \& Klein, 1973; Yair \& Lavee., 1974; Yair, 1983; Yair, 1987; Shor, 1987; Yair \& Raz-Yassif, 2004). Yair (1983) measurements noted the threshold of rainfall intensity for generating runoff on rocky surfaces to be in the order of 1-3 mm/hour for the massive limestone Shivta Formation, while for the loessic soil covered slopes this threshold is in the order of 3-5 mm/hour. However, gaps and uncertainties exists when testing spatial distribution of arid rocky slopes to generate runoff. Furthermore, possible synthesis between hillslope vegetation patterns to hillslope runoff yield within arid regions was mainly conducted in small scale basin (Yair \& Danin, 1980; Olswig-Whittaker et al., 1983; Hikel et al., 2012; Shor, 1987). Thus, such studies represent only a limited scope of the spatial distribution of the rain-bedrock-runoff in broader regions. Therefore, Yair and his colleagues, following their study at the Sede Boqer 
experimental site on three Turonian Formations, Derorim, Shivta and Nezer consisting of different lithologies (chalk and marl, massive limestone and well bedded limestone, respectively) point out the need for more specific research in order to get the full picture of runoff generation on different rocky slopes and vegetation patterns in a desert environment. This step is critical for testing both slope and basin scale.

Fig. 1: Location map - Red rectangle indicates research area; White lines indicate isohyets (after Evenari et al., 1982)

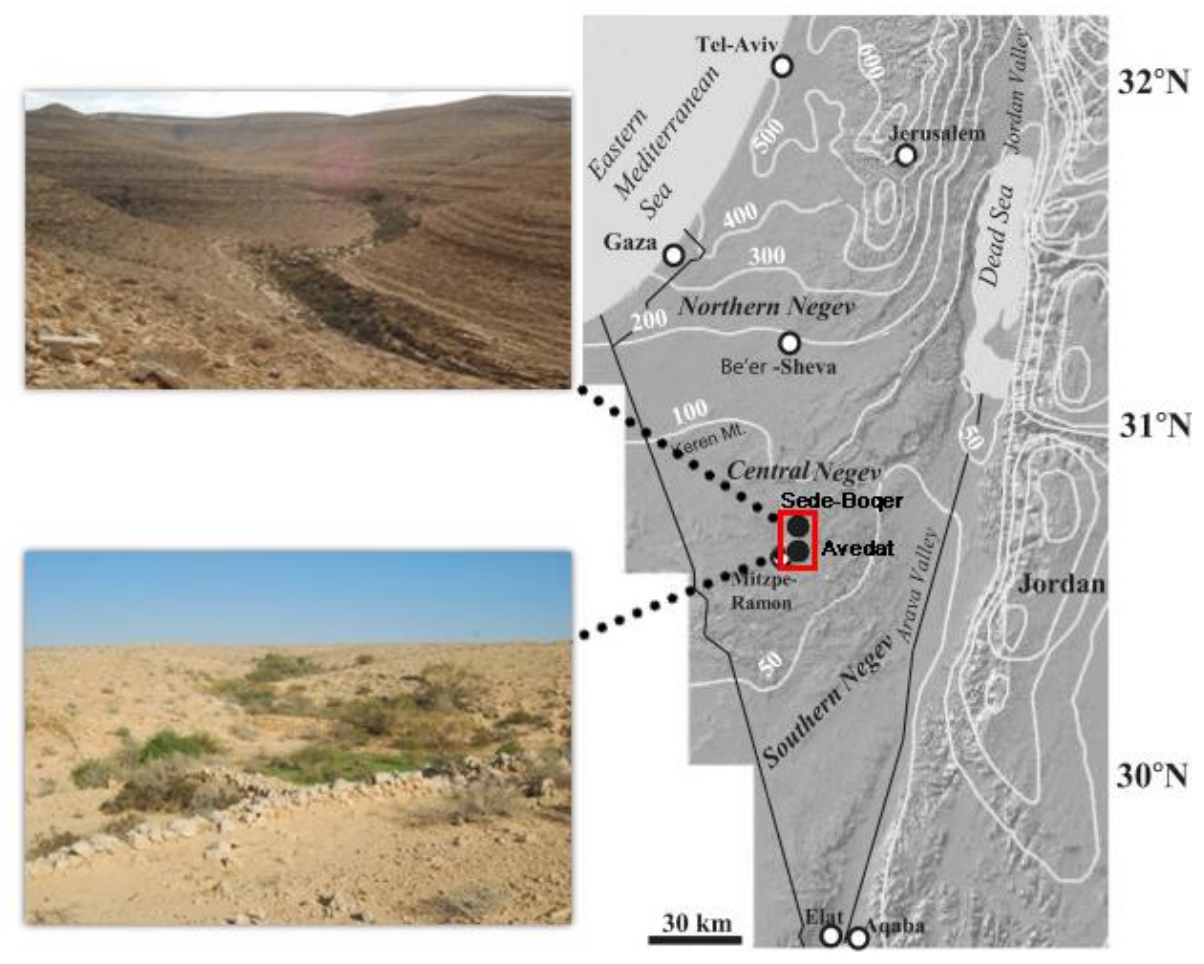

Soil permeability and runoff generation on soils are domains, which have been extensively studied (e.g. Shanan et al., 1963; Evenari et al., 1982; Yair, 1983; Lavee et al., 1997). Soils reservoir dynamics along bedrock slopes in arid environments was suggested to be locally correlated with landscape curvature (Amundson et al., 2015). Amundson et al. (2015) further suggested that the maximum thickness that soils attain on arid hillslope might be plant regulated. Bare rock surfaces along the slopes act as a water and sediment source while vegetated patches act as a sink (i.e., trap) for these water and sediments. This scenario exists due to the higher values of soil porosity, infiltration capacity and low bulk density. A semi-quantitative analysis carried out by Olswig-Whittaker et al. (1983) in the Negev Desert, indicated that rock soil ratio can serve as a simple guide to predict soil moisture variability and hence the spatial distribution of vegetation growth. Assessing the spatial relations between the bedrock runoff generation and vegetation patterns it may imply on spatial locations of Byzantine agriculture installations. Evenari et al., (1982) examined the provisions of water to the Byzantine agriculture installations and the runoff harvesting installations constructed by the ancient farmers. Studies carried out by Evenari et al. (1982); 
Wieler N., Avni Y., Rosensaft M., Olsvig-Whittaker L.: Variations in hillslope runoff as detected using geological strata coupled with vegetation patterns- implications on spatially distributed desert runoff agriculture

Yair, (1983); Bruins, (2012); and Bruins \& Ore, (2009) noted that this type of ancient agriculture was based on runoff harvesting and not on direct rain precipitation. Thus, they highlighted the importance of rain- bedrock-runoff relations as a vital component of the desert agriculture, which was based on sophisticated runoff harvesting techniques (Tadmor at al., 1961; Shanan et al., 1963; Evenari et al., 1982; Yair, 1983; Lavee et al., 1997; Droppelmann et al., 2000; Bruins \& Ore, 2009). Yet, since the early $20^{\text {th }}$ century, a pendulum of theories exists regarding the presence of the agriculture installations. Some assume that climate changes, transforming humid regions into desert zones, are responsible for the ability of ancient farmers to practice agricultural activities in today's desert (Huntington, 1911; Issar \& Zohar, 2004; Orland et al., 2009), while others argue for late Holocene climate stability (Nevo, 1991; Liphschitz, 1996). Testing speleothems in the Negev Desert were used as paleoclimate markers (Vaks et al., 2010). Their findings showed that even through more humid periods, the vegetation in the Negev Desert, Israel, remained semi-arid, C4 type. Based on our previous results (Wieler et al., 2016), we aim to use the perennial vegetation patterns found along the desert rocky slopes as a runoff proxy tool that will imply on the locations of the ancient agriculture installations.

\section{Site description}

The Negev Highlands west of Sede Boqer (Fig. 1, Table 1), as described in Wieler et al. (2016) is an arid rocky terrain (P/PET=0.05) (Bruins \& Ore, 2009; UNESCO, 1979), comprising diverse geological strata (Table 2) along with different vegetation patterns. Soils along the Negev Desert rocky slopes are very shallow, except the shallow colluvium composed of a mixture of rock fragments and aeolian loess. This type of colluvium is found along rocky slopes of the Tamar, Derorim, Mor and Horsha, Formations (Yair \& Danin, 1980; Wieler et al., 2016). These soils were classified as desert brown lithosols (Arkin \& Braun, 1965; Dan et al., 1972; Yaalon \& Dan, 1974).

\section{Table 1: Charasteristics of the Sede Boqer study area sites}

\begin{tabular}{|c|c|}
\hline Parameter & Sede-Boqer vicinity \\
\hline $\begin{array}{l}\text { Elevation } \\
\text { (meters above sea level) }\end{array}$ & $400-700$ \\
\hline $\begin{array}{l}\text { Annual rain precipitation } \\
\left(\mathrm{mm} \mathrm{yr}^{-1}\right)(\mathrm{P})\end{array}$ & $80-120$ \\
\hline Potential evaporation (mm) (PET) & 2000 \\
\hline $\begin{array}{l}\text { Aridity Index }(\mathrm{P} / \mathrm{PET}) \\
(\mathrm{UNESCO}, 1979)\end{array}$ & Arid (0.05) \\
\hline Bedrock units & $\begin{array}{l}\text { Late Cretaceous to Tertiary age, consists of marine sediments } \\
\text { mainly limestone, dolomite, chalk, marl and chert }\end{array}$ \\
\hline Distance to nearest sea & $80 \mathrm{~km}$ to the Mediterranean sea and $140 \mathrm{~km}$ to the Red sea \\
\hline Rain source & $\begin{array}{c}\text { Mediterranean sea and } \\
\text { Red sea trough }\end{array}$ \\
\hline Rain season & December to March \\
\hline Annual average rain days amount & 27 \\
\hline Annual average dew days amount & 200 \\
\hline Annual average dew precipitation $(\mathrm{mm})$ & 20 \\
\hline Dew point & $7-14^{\circ} \mathrm{C}$ \\
\hline Annual average fog days amount & NA \\
\hline Mean annual temperature & $5-40^{\circ} \mathrm{C}$ \\
\hline Annual average relative humidity (\%) & 40 \\
\hline
\end{tabular}


Table 2: Characterization of the geological strata (from old to young) exposed in the study area

\begin{tabular}{|c|c|c|c|c|c|c|}
\hline $\begin{array}{l}\text { Group } \\
\text { name }\end{array}$ & $\begin{array}{c}\text { Spatial } \\
\text { appearance }\end{array}$ & Age & $\begin{array}{c}\text { Formation } \\
\text { name }\end{array}$ & $\begin{array}{l}\text { Exposed } \\
\text { thickness } \\
\text { (meters) }\end{array}$ & Lithology & $\begin{array}{c}\text { Slope } \\
\text { morphology }\end{array}$ \\
\hline \multirow{4}{*}{ Judea } & \multirow{4}{*}{$\begin{array}{l}\text { Exposed in } \\
\text { anticlinal } \\
\text { structures }\end{array}$} & \multirow{4}{*}{$\begin{array}{c}\text { Cenomanian } \\
\text { to Turonian }\end{array}$} & Zafit & 30 & $\begin{array}{c}\text { Dolomite and } \\
\text { marly } \\
\text { dolomite, } \\
\text { chert nodules }\end{array}$ & $\begin{array}{l}\text { Forming well } \\
\text { bedded small } \\
\text { banks. Located at } \\
\text { the bottom of the } \\
\text { exposed } \\
\text { geological section }\end{array}$ \\
\hline & & & Avnon & 42 & $\begin{array}{l}\text { Limestone } \\
\text { and dolomite }\end{array}$ & $\begin{array}{c}\text { Forming hard } \\
\text { cliffs and massive } \\
\text { banks }\end{array}$ \\
\hline & & & Derorim & 9 & $\begin{array}{c}\text { Chalky } \\
\text { limestone and } \\
\text { marl }\end{array}$ & $\begin{array}{c}\text { Forming short } \\
\text { slopes }\end{array}$ \\
\hline & & & Shivta & 36 & $\begin{array}{l}\text { Massive } \\
\text { bioclastic } \\
\text { limestone }\end{array}$ & $\begin{array}{l}\text { Forming hard } \\
\text { cliffs and long } \\
\text { rocky slopes }\end{array}$ \\
\hline \multirow{4}{*}{$\begin{array}{l}\text { Mount } \\
\text { Scopus }\end{array}$} & \multirow{4}{*}{$\begin{array}{l}\text { Synclinal } \\
\text { structures }\end{array}$} & \multirow{4}{*}{$\begin{array}{c}\text { Santonian to } \\
\text { Paleocene }\end{array}$} & Menuha & 11 & Massive chalk & $\begin{array}{c}\text { Forming long } \\
\text { slopes }\end{array}$ \\
\hline & & & Mishash & 6 & $\begin{array}{l}\text { Brecciated } \\
\text { chert and } \\
\text { some } \\
\text { phosphate } \\
\text { layers }\end{array}$ & $\begin{array}{c}\text { Forming rock } \\
\text { fragments } \\
\text { covering large } \\
\text { slopes }\end{array}$ \\
\hline & & & Ghareb & 51 & $\begin{array}{c}\text { Chalk and } \\
\text { marl }\end{array}$ & $\begin{array}{l}\text { Forming long } \\
\text { slopes and some } \\
\text { banks }\end{array}$ \\
\hline & & & Taqiye & 21 & Clay & $\begin{array}{c}\text { Forming long } \\
\text { slopes }\end{array}$ \\
\hline
\end{tabular}


Wieler N., Avni Y., Rosensaft M., Olsvig-Whittaker L.: Variations in hillslope runoff as detected using geological strata coupled with vegetation patterns- implications on spatially distributed desert runoff agriculture

\begin{tabular}{|c|c|c|c|c|c|c|}
\hline $\begin{array}{c}\text { Group } \\
\text { name }\end{array}$ & $\begin{array}{c}\text { Spatial } \\
\text { appearance }\end{array}$ & Age & $\begin{array}{c}\text { Formation } \\
\text { name }\end{array}$ & $\begin{array}{l}\text { Exposed } \\
\text { thickness } \\
\text { (meters) }\end{array}$ & Lithology & $\begin{array}{c}\text { Slope } \\
\text { morphology }\end{array}$ \\
\hline \multirow{3}{*}{ Avedat } & \multirow{3}{*}{$\begin{array}{l}\text { Avedat } \\
\text { plateau }\end{array}$} & \multirow{3}{*}{$\begin{array}{l}\text { Early to } \\
\text { Middle } \\
\text { Eocene }\end{array}$} & Mor & 3 & $\begin{array}{l}\text { Chalk and } \\
\text { chert nodules }\end{array}$ & $\begin{array}{l}\text { Forming short } \\
\text { slopes }\end{array}$ \\
\hline & & & Nizzana & 47 & Limestone & $\begin{array}{l}\text { Forming long } \\
\text { rocky slopes. Mor } \\
\text { and Taqiye } \\
\text { formation slopes } \\
\text { are covered in } \\
\text { places with } \\
\text { Nizzana } \\
\text { Formation } \\
\text { landslides } \\
\end{array}$ \\
\hline & & & $\begin{array}{c}\text { Horsha and } \\
\text { Matred } \\
\text { (named also } \\
\text { Nahal } \\
\text { Yeter) }\end{array}$ & 40 & $\begin{array}{l}\text { Massive chalk } \\
\text { and limestone }\end{array}$ & $\begin{array}{l}\text { Long chalky steep } \\
\text { slopes in the lowe } \\
\text { and central part } \\
\text { (Horsha Fm.), } \\
\text { long rocky limey } \\
\text { slopes at the upper } \\
\text { part (Matred Fm.) }\end{array}$ \\
\hline
\end{tabular}

\section{Archeological background}

Two major ancient desert cities from the Roman-Byzantine times $\left(3-7^{\text {th }}\right.$ centuries AD), Avedat and Shivta - were located at the edges of the study area (Fig. 1) and more than 30,000 hectares (Avni et al., 2012) of ancient agricultural installations are distributed in this area (Avni et al., 2013; Avni, 2014). The existence and maintenance of these installations is largely controversial. Some assume that climate changes, transforming humid regions into desert zones, are responsible for the ability of ancient farmers to practice agricultural activities in today's desert (Huntington, 1911; Issar \& Zohar, 2004; Orland et al., 2009), while others argue for late Holocene climate stability (Nevo, 1991; Liphschitz, 1996). Detailed mapping of the agriculture installations in broad areas within the Negev Highlands reveal two types of agricultural installations. Type one are agriculture fields located in a range size of wadis, directly irrigated by flood runoff. Most of the crops within these plots were annual cereals such as wheat and barley (Ashkenazi et al., 2012) (Fig. 2). Type two are agriculture fields located mainly in small wadis irrigated by overland flow collected from adjoining slopes and from small streams using earth and stone channels (Evenari et al., 1982; Ashkenazi et al., 2012). These fields were designed to trap flood water by erecting stone and earth embankments allowing relatively large volumes of water to accumulate and deep percolation of the trapped water into the soil. Most of the crops within them were perennials such as olive trees and grapevines (Fig. 3). 
Fig. 2: Cultivated fields in Sede Boqer region. The straight lines crossing the wadi bed are low, 1-2 courses of stone terrace walls $(0.5-0.8$ meter high). These fields irrigated by controlling channels from the main wadi.

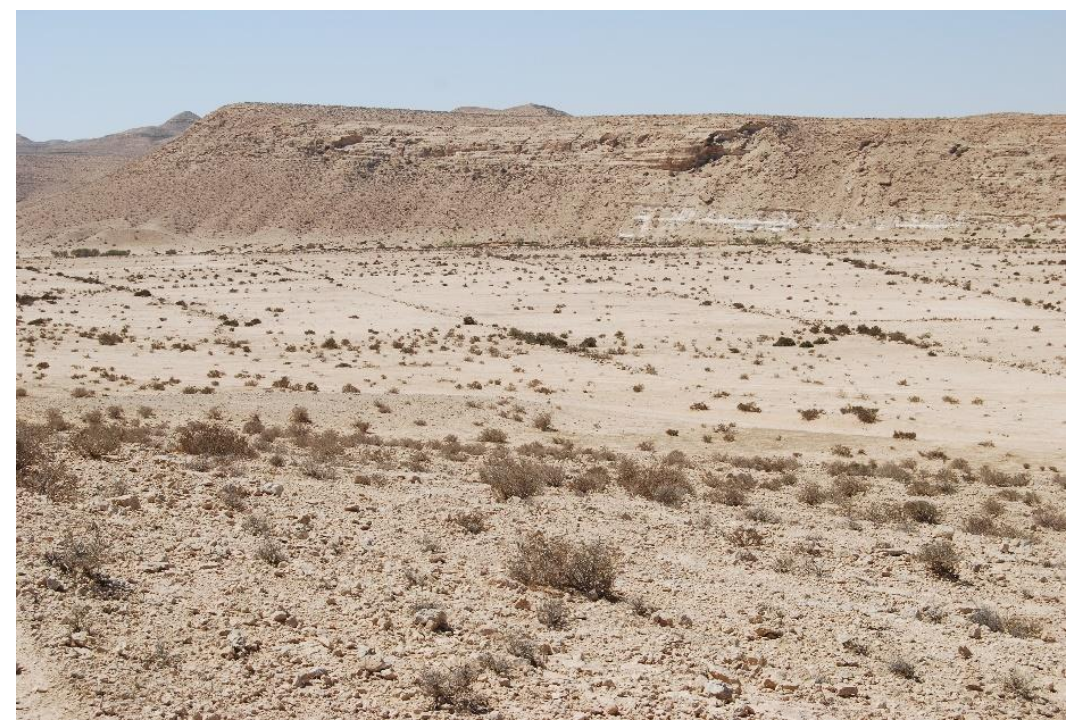

Fig. 3: Small wadi cultivated field in Sede Boqer region, containing 3-4 courses of stone terrace walls (1.2-1.5 meter high)

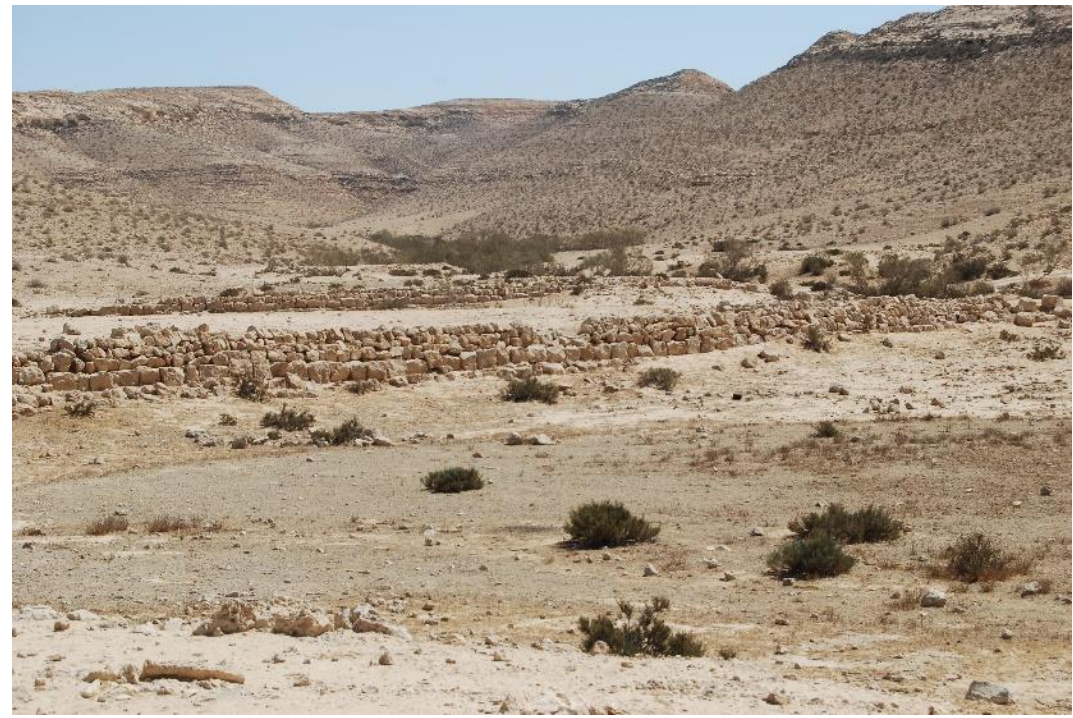

Coupling the long-term climatic discussion with the spatial distribution of the discussed installations, one would expect that in humid climatic conditions the installations will be spread all over the area and not concentrated within specific locations. On the other hand, under arid conditions it is not clear what were the primary conditions needed for locating the different agriculture plots. Therefore, we suggest applying a multi-disciplinary approach over a large area $\left(160 \mathrm{~km}^{2}\right)$. We hypothesize that testing variations in the sparse perennial 
Wieler N., Avni Y., Rosensaft M., Olsvig-Whittaker L.: Variations in hillslope runoff as detected using geological strata coupled with vegetation patterns- implications on spatially distributed desert runoff agriculture

vegetation patterns along diverse lithologies will act as a precursor for defining rain-bedrock-runoff relations. Thus, examining the correlation between the rain-bedrock-runoff, vegetation patterns and ancient agricultural installations will reflect the past historical environment and climate conditions.

The aims of the present paper are:

1. To expand the study on rock and vegetation patterns as a proxy for runoff generations in desert rocky slopes environments, first discussed by Yair \& Danin (1980); Olswig-Whittaker et al. (1983); and Hikel et al. (2012), to a wider geological rock units covering the majority of the Negev Highland region.

2. Based on the GIS procedure presented by Wieler et al. (2016) we aimed at elaborating a potential runoff map merging geological strata, vegetation patterns and surface properties, representing the entire region of the Negev Highlands.

3. To evaluate the correlation between the present runoff potential on the drainage basin scale and the spatial distribution of the historical runoff-farms within the same region. If the ancient farms were constructed solely within the present highly productive runoff zones, we could conclude that the past desert conditions were fundamentally similar to those that exist in the region at present. On the other hand, poor or no correlation between the two go well with the hypothesis of Huntington, (1911) and Issar \& Zohar (2004) claiming that a much more humid climate prevailed during historical times, enabling the flourishing of the desert agriculture in the entire region with no restriction to a specific highly productive runoff zones.

Although the study focuses on the central part of the Negev Highlands of southern Israel, this region is a good representative of the geological diversity composing large regions in the Middle East arid zone. Therefore, with some necessary adjustments to local conditions in each region, the methodological approach presented here could be applicable to other arid zones worldwide.

\section{METHODS OF WORK}

The research methodology is a synthesis framework of the following inter-related data sets: A geological field survey: The survey conducted by Wieler et al. (2016) characterized the main rock formations exposed in the Negev Highlands. This was done by conducting detailed geological stratigraphic sections.

Geological mapping: In order to verify the geographic distribution of these rock formations in a diagnostic region in the Negev Highlands, Wieler et al. (2016) mapped an area of $160 \mathrm{~km}^{2}$ on a 1:50,000 scale according to the stratigraphic divisions made in the former step. This area was selected in the aim of representing most of the rock types exposed in the Negev Highlands.

Geotechnical lab tests: This step included laboratory experiments that were carried out on fourteen rock samples. These rock samples were selected from the stratigraphic sections, covering the range from the Cenomanian Avnon Formation to the Middle Eocene Matred Formation, representing each rock formation and covering the majority of the rock types exposed in the region. In accord with a procedure that included rain simulation experiments and geotechnical tests such as bulk dry density, water absorbance and water absorption profiles, Wieler et al. (2016) defined the rock characteristics and determined a quantitative runoff coefficient for the fourteen rock types.

Geo-botanical field survey: This survey tested the relationship between the chief botanical components and surface properties along variety of geological strata to form comparable 
eco-hydrologic units. The results of the field survey were analyzed using multivariate analyses, which were conducted on the CANOCO 4.5 software and its default options following the methodology presented in Braak \& Smilauer (2002). Based on the geo-botanical parameters we developed a relative geo-botanical runoff coefficient scale for all rock types exposed in the region. See detailed methodology below.

Geo-archeological field survey: This survey, overlapping the geological mapping, based on a previously published survey of Cohen (1985), was made to re-examine and evaluate the location and functionality of the desert agriculture installations.

We carried out spatial analyses of these five data sets using the ARC/INFO 9.3 GIS tool; for the detailed methodology dealing with the first three data sets along with the GIS procedure see Wieler et al. (2016). The chart flow presented below (Fig. 4) summarizes the GIS methodology that we used in order to integrate the data sets.

Fig. 4: Flow chart showing data processing with the GIS tool

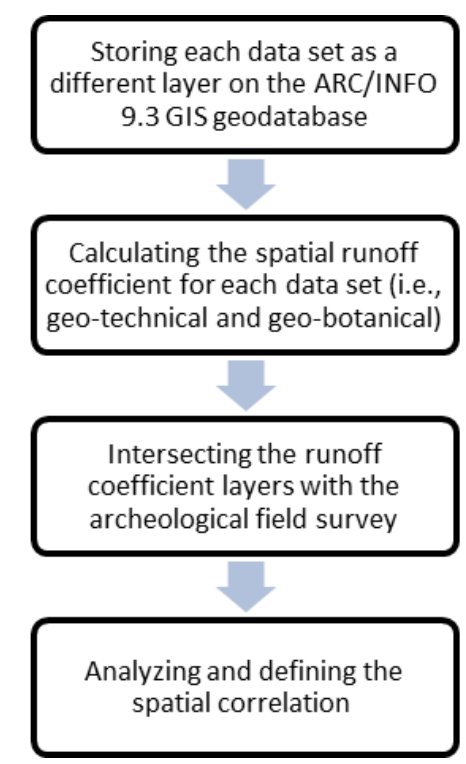

\section{Geo-botanical field survey}

Perennial vegetation patterns located in desert environments along rocky slopes expresses the water and sediment availability for each plant community (Yair \& Danin, 1980; Danin, 1983). Following this idea, we used the perennial vegetation on slopes composed of discreet geological formation as an environmental proxy reflecting the runoff generation. In the context of the current research, it enabled up scaling the geo-technical lab tests into the drainage basin scale.

The vegetation can serve as an indicator for runoff generation under the following settings:

Pattern A: The slope is covered by vegetation in a well distributed pattern and the type of vegetation is in accordance with the multi-annual precipitation rate. This pattern is developed when almost all the annual precipitation is percolated along the slope with almost no runoff contribution to the bottom of the slope.

Pattern B: Only some parts of the slope are covered by vegetation and the type of vegetation is indicating enrichment in the water availability, especially within creeks and soil patches. This pattern is developed when part of the slope is covered by unpenetrated rock 
Wieler N., Avni Y., Rosensaft M., Olsvig-Whittaker L.: Variations in hillslope runoff as detected using geological strata coupled with vegetation patterns- implications on spatially distributed desert runoff agriculture

surfaces that generate runoff and contribute it to other areas along the slope. As the slope consists larger portions of unpenetrated rock surfaces, it yields more runoff. The relative amount of runoff can be indicated by the relative area covered by vegetation and the structure of vegetation community, such as high percentage of species of Mediterranean or Irano-Turanian chorotypes relative to Saharan-Arabian (Danin, 1983; see Table 3).

Table 3: Characterization of the subjected vegetation and their chorotypes, exposed in the study area

\begin{tabular}{|c|c|}
\hline Vegetation & Chorotype \\
\hline Zygophyllum dumosum & B \\
\hline & A \\
\hline Hammada salicornica & $\mathrm{B}, \mathrm{D}$ \\
\hline Reaumuria hirtella & $\mathrm{B}, \mathrm{C}$ \\
\hline Fagonia mollis & B \\
\hline Noaea mucronata & $\mathrm{B}, \mathrm{C}$ \\
\hline Artemisia herba-alba & $\mathrm{C}$ \\
\hline Echinops polyceras & $\mathrm{C}$ \\
\hline Origanum ramonense & $\mathrm{C}$ \\
\hline Retama raetam & B \\
\hline Helianthemum vesicarium/ aegyptiacum & $\mathrm{C}$ \\
\hline Ballota undulate & A \\
\hline Gymnocarpos decandrum & B \\
\hline Haloxylon persicum & $\mathrm{B}, \mathrm{C}$ \\
\hline Anabasis articulate & B \\
\hline Achillea fragrantissima & $\mathrm{C}$ \\
\hline Varthemia iphionodes & A \\
\hline Pituranthos tortuosus & B \\
\hline Asparagus aphyllus & A \\
\hline Stachys aegytiaca & B \\
\hline Hammada scoparia & $\mathrm{B}, \mathrm{D}$ \\
\hline Zilla spinosa & B \\
\hline Thymelaea hirsute & $\mathrm{A}, \mathrm{B}$ \\
\hline Astragalus spinosus & B \\
\hline
\end{tabular}

A- Mediterranean; B- Saharo-Arabian; C- Irano-Turanian; D- Sudanian

Pattern C: Slopes which lack or sparsley vegetated, and the type of vegetation is in accordance with the arid conditions. This pattern is developed when the slope consists of soft permeable strata (i.e., marl and clay), leading to high percolation along the slope with almost 
no runoff contribution to the bottom of the slope. High percolation along the shallow (5-15 $\mathrm{cm}$ ) soft permeable column along with high evaporation rate cause increase in the salinity of the slope, thus effecting the vegetation type and density.

To assess the relative impact of the geological strata along with different environmental variables upon the perennial vegetation (i.e. stone coverage along the slope, slope length, slope inclination, slope aspect, soil rock ratio and percentage of cliffs along the slope), experimental plots were established on slopes of each geological formation (see table 4). Each formation was represented by two to four $10 \times 10 \mathrm{~m}^{2}$ plots. The species that grow in the plots, their frequency and canopy cover percentage were determined in each plot (see table 4). Vegetation cover data were recorded using the procedure and scale presented by the EBONE project (Gerard et al. 2012). The EBONE project is based on plant life forms and is recognized as a robust means of defining the essential character of habitats throughout the world. We found the EBONE project methods applicable to our study since its aims were to develop standardized field recording system and to provide valid, statistical estimates of habitats and biodiversity.

\section{Data analysis:}

In this paper, we used Redundancy Analysis (RDA) to investigate the floristic characteristics of plant communities and patterns in species distribution relative to a number of measured environmental variables (i.e. stone coverage along the slope, slope length, slope inclination and slope aspect). RDA expresses species relationships as linear combinations of environmental variables. RDA was performed using the CANOCO software (Braak \& Smilauer, 1988). The CANOCO software allowed checking the hierarchy and relative importance of the different environmental factors in a graphic format (for explanation on the CANOCO software see Lep \& Similauer, 2003). Using the graphic format we managed to correlate specific flora, defined according to their chorotype, to the subjected environmental variables.

Applying this procedure, we defined eco-hydrological units (Hikel et al., 2012) and set a semi-quantitative relation between them and surface properties. We then correlated the semi-quantitative scale to the different geological formations on the GIS system and thus formed a geo-botanical runoff map (map no.1). This map enabled us to reflect the spatial appearance of different vegetation patterns in the region. 
Table 4: Bioindicators data for the subjected lithologies

\begin{tabular}{|c|c|c|c|c|c|c|c|c|c|c|c|c|c|c|c|c|c|c|c|c|c|c|c|c|c|c|c|c|c|c|c|c|c|c|c|c|c|c|c|c|c|c|c|c|c|c|c|c|c|}
\hline Parameter & \multirow{2}{*}{ 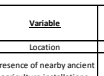 } & \multirow{2}{*}{ 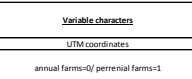 } & \multicolumn{3}{|c|}{ 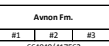 } & \multicolumn{4}{|c|}{ Tsmantm } & \multicolumn{3}{|c|}{ 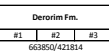 } & \multicolumn{4}{|c|}{ 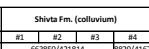 } & \multicolumn{4}{|c|}{ 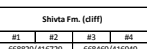 } & \multicolumn{3}{|c|}{ 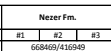 } & 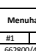 & & 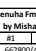 & & 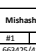 & & 6hasebt & & 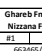 & 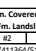 & & & net & in & 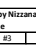 & & Nizanat & & 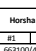 & & & & & & & \\
\hline & & & 1 & 1 & 1 & 1 & 1 & 1 & . & 1 & 1 & 1 & 1 & 1 & 1 & 1 & 1 & 1 & 1 & 1 & 1 & 1 & 1 & . & 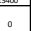 & . & 0 & . & 。 & 。 & 。 & 0 & 。 & 。 & 1 & 1 & 1 & 1 & & & 1 & & & & & 1 & 1 & 1 & \\
\hline & Strem size order & 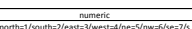 & 2 & 2 & 2 & 1 & 1 & 1 & 2 & 1 & 1 & 1 & 1 & 1 & 1 & 1 & 1 & 1 & 1 & 1 & 1 & 1 & 1 & 1 & 1 & 2 & 2 & 1 & 1 & 1 & 1 & & 1 & 1 & 1 & 1 & 1 & 1 & 1 & & & 1 & 1 & 1 & 1 & 1 & 1 & 2 & 2 \\
\hline Gener & Slope aspett & & 1 & 2 & 4 & 2 & ${ }^{4}$ & 1 & ${ }^{6}$ & 2 & 4 & 1 & ${ }^{2}$ & ${ }^{4}$ & 1 & ${ }^{2}$ & 1 & 2 & & ${ }^{5}$ & 3 & & 5 & 2 & 1 & 1 & 2 & 4 & 1 & & & & 2 & & & & 6 & & & & & 2 & & 6 & & ${ }^{4}$ & & ${ }^{2}$ & \\
\hline & 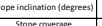 & 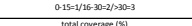 & 2 & $3^{3}$ & $r^{2}$ & $2^{2}+2+3$ & 2 & 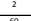 & $3^{3}$ & 2 & ${ }^{2}$ & $2^{2}+2$ & 2 & 2 & 2 & 2 & 2 & 2 & 1 & 1 & 1 & 1 & & 2 & $2^{2}$ & & & 1 & 1 & & ${ }^{2}$ & & 2 & 2 & 2 & & 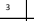 & 1 & 1 & $3^{3}>0$ & 3 & ${ }^{3}$ & $3^{3}$ & & & & & 2 & $2^{2}+3 x$ \\
\hline & Stone cove & 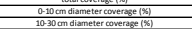 & $\begin{array}{ll}40 \\
40 \\
40\end{array}$ & $\frac{200}{20}$ & $\begin{array}{ll}\frac{30}{300} \\
30\end{array}$ & 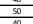 & $\begin{array}{ll}50 \\
40 \\
40\end{array}$ & $\begin{array}{l}\frac{60}{30} \\
30\end{array}$ & 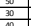 & $\frac{60}{40}$ & 然 & $\begin{array}{cc}-\infty \\
60 \\
60\end{array}$ & $\begin{array}{l}\frac{30}{40} \\
50 \\
40\end{array}$ & $\frac{30}{400}$ & $\frac{60}{60}$ & $\frac{-30}{40}$ & 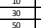 & $\frac{30}{400}$ & $\frac{30}{60}$ & 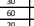 & $\frac{20}{60}$ & $\frac{40}{40}$ & . & $\frac{\infty}{x}=$ & 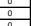 & 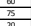 & .65 & $\frac{50}{100}$ & at & & o & 40 & & & 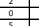 & 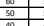 & & & & 50 & 50 & & 50 & 40 & 40 & 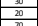 & $\frac{30}{20}$ & $\begin{array}{l}\frac{30}{40} \\
409\end{array}$ & 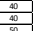 \\
\hline & 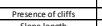 & 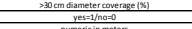 & $\frac{20}{1}$ & $\begin{array}{ll}\frac{50}{1} \\
1\end{array}$ & $\begin{array}{ll}20 \\
0 \\
0\end{array}$ & 售 & $\frac{20}{0}$ & $\frac{20}{0}$ & $\begin{array}{l}30 \\
0.0 \\
\end{array}$ & $\frac{20}{0}$ & $\frac{20}{0}$ & 20 & $\frac{10}{1}$ & 10 & 10 & $\frac{10}{10}$ & $\frac{20}{1}$ & 10 & 10 & 20 & $\frac{10}{0}$ & $\frac{20}{0}$ & & $\frac{0}{\circ}$ & 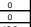 & +2 & $\frac{5}{0}$ & 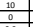 & 竞 & & & $\frac{20}{0}$ & & & & 10 & & & & & & & & & & & 1 & $\frac{1}{1}$ & $\frac{30}{10}$ \\
\hline & 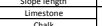 & & & & & & & 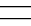 & & $\frac{20}{200}$ & $\frac{9}{20}$ & $\frac{90}{20}$ & $\begin{array}{ll}\frac{1.2}{30} \\
30\end{array}$ & $\begin{array}{ll}9 \\
30\end{array}$ & & & & & & & & & 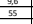 & 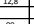 & 100 & 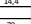 & 12,4 & & & & & & 1102 & & & & & & & & & & & & & & & & \\
\hline & 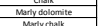 & & 10 & 10 & 10 & 15 & 15 & 15 & 15 & & 10 & 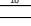 & 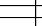 & ב- & 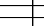 & 怘 & 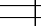 & 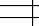 & 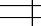 & 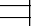 & 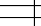 & ב & 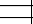 & - & 100 & 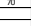 & to & 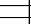 & & & 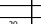 & 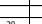 & 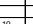 & & 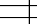 & in & 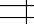 & 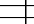 & E & 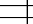 & 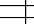 & 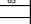 & $E$ & & & 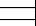 & ב & 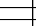 & E \\
\hline & 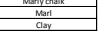 & & - & - & t & 40 & 40 & 40 & $\infty$ & 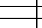 & 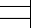 & 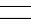 & 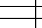 & 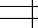 & ב & E & 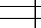 & $=$ & - & - & - & 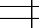 & 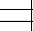 & $\Rightarrow$ & 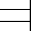 & 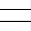 & 然 & 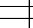 & - & 80 & $\begin{array}{l}\frac{200}{800} \\
80\end{array}$ & $\frac{20}{50}$ & 势 & 40 & $\infty$ & ${ }_{10}$ & & 20 & 20 & & & & $E$ & 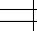 & & -1 & $\Rightarrow$ & 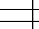 & E \\
\hline 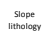 & 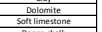 & 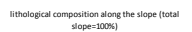 & $x^{2}$ & 70 & $\begin{array}{ll}x^{n} \\
\end{array}$ & 30 & 30 & 30 & 30 & \begin{tabular}{|l|l|}
$\infty$ & \\
\end{tabular} & 40 & 20 & 25 & 20 & 20 & 15 & E & 20 & E & $\mathrm{ft}$ & 20 & 20 & 20 & - & $\theta$ & E & {[} & E & -5 & $=$ & 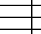 & 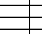 & E & $\bar{Z}$ & $=$ & & 胥 & 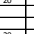 & 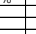 & ${ }^{30}$ & 30 & 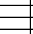 & 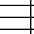 & 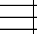 & & 10 & ${ }_{10}$ & 5 & 5 \\
\hline & 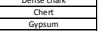 & & 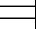 & 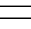 & 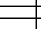 & E & $\Rightarrow$ & 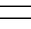 & 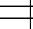 & 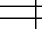 & 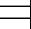 & $\overline{-}$ & 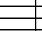 & $\overline{-}$ & $\overline{-}$ & 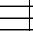 & 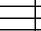 & $\overline{-}$ & $\overline{-}$ & $\overline{-}$ & $=$ & $=$ & 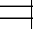 & 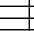 & 致 & 10 & ${ }_{10}$ & 2 & 80 & 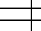 & ב- & 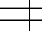 & $E$ & 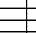 & 10 & ${ }^{20}$ & 集 & 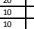 & $\frac{10}{10}$ & 10 & 10 & E & E & $\Rightarrow$ & E & $\Longrightarrow$ & $\Rightarrow$ & $5^{5}$ & 5 \\
\hline & $\begin{array}{c}\text { Collovium } \\
\text { llituon }\end{array}$ & & 10 & 10 & \begin{tabular}{|l|l|l|l|}
10 \\
10
\end{tabular} & $\frac{10}{5}$ & 10 & $\frac{10}{15}$ & $\frac{10}{5}$ & 30 & 30 & 30 & ${ }^{45}$ & 50 & 50 & 5 & 10 & 10 & I5: & to & 15 & 15 & $\frac{15}{10}$ & ${ }^{10}$ & 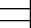 & 20 & 20 & to & 20 & & 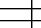 & $\frac{10}{10}$ & $\frac{20}{30}$ & $\frac{30}{10}$ & 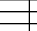 & 放 & 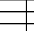 & - & 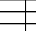 & 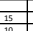 & . & 10 & 槅 & (1) & 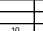 & 10 & $\frac{10}{10}$ & 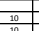 & $\frac{10}{10}$ \\
\hline & incestre & & 0.25 & 0.25 & 0.25 & 0.18 & 0.18 & 0.18 & 0.18 & $\begin{array}{ll}0.60 \\
\end{array}$ & 0.000 & 0.00 & \begin{tabular}{|l|l}
0.82 & \\
\end{tabular} & \begin{tabular}{l|l}
1,00 \\
100
\end{tabular} & $1, \infty$ & 1.22 & $\begin{array}{ll}0.11 \\
\end{array}$ & 0.05 & 0.18 & s.tit & $\begin{array}{ll}0.33 \\
0.33\end{array}$ & (a.3 & 0.03 & 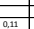 & 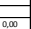 & .0.25 & 0.25 & 2.25 & & $0,0,0,0$ & 0,000 & 0.25 & $\frac{1.67}{0.67}$ & 0 & 0.00 & 0.43 & & 0.00 & 0.00 & 然3 & & 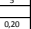 & 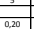 & 0.13 & 0.13 & 0.25 & 0.25 & 0.25 & 0.25 \\
\hline & 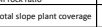 & total covernge (x) & 30 & 20 & 30 & 10 & ${ }_{12}$ & (2) & 年 & ${ }_{10}$ & 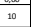 & 15 & 30 & 30 & 35 & 30 & 20 & 25 & so & 20 & 25 & 25 & ${ }_{25}$ & s & 5 & 10 & 10 & 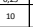 & 10 & 0 & 2 & $\frac{16}{4}$ & 10 & 10 & 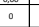 & ${ }_{10}$ & 5 & 2 & $\frac{10}{2}$ & 17 & 18 & 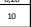 & 然 & 5 & 5 & 20 & 20 & 20 & $\frac{200}{30}$ \\
\hline & 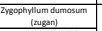 & & 20 & 2 & 20 & $\infty$ & 50 & 30 & 10 & $\infty$ & 70 & 50 & \begin{tabular}{|c|}
50 \\
\end{tabular} & 20 & ${ }_{10}^{10}$ & 10 & 2 & ${ }_{10}^{10}$ & ${ }_{10}^{10}$ & 20 & 40 & 40 & 30 & $\infty$ & $+\infty$ & 55 & ${ }_{100}$ & 2 & 100 & & $\infty$ & 50 & $\infty$ & 40 & & $\infty$ & 2 & $\frac{\pi}{n}$ & 10 & $\infty$ & 80 & 30 & 10 & 70 & $\infty$ & & 5 & & 2 \\
\hline & 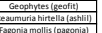 & & $\begin{array}{l}\frac{5}{20} \\
2\end{array}$ & $\frac{2}{50}$ & $\frac{2}{20}$ & 10 & ${ }_{10}$ & 30 & $\frac{2}{30}$ & ${ }_{10}$ & ${ }_{10}$ & 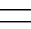 & 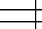 & \begin{tabular}{l|l}
5 \\
15 \\
\end{tabular} & $\frac{5}{15}$ & $\frac{2}{4}$ & $a^{4}$ & \begin{tabular}{l|l}
$\frac{2}{4}$ \\
\end{tabular} & 2 & 2 & 2 & $\frac{2}{10}$ & 10 & & 20 & $\begin{array}{c}5 \\
10 \\
\end{array}$ & & E & & & 20 & 30 & 20 & 20 & & $\frac{2}{2}$ & 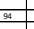 & 20 & 90 & $\frac{2}{2}$ & $\frac{2}{2}$ & $\frac{2}{10}$ & 量 & & 40 & & $E$ & & 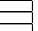 \\
\hline & 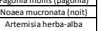 & & 10 & 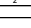 & 20 & & 20 & $10^{\circ}$ & 30 & & ${ }_{10}$ & 10 & ${ }_{10}$ & 20 & 20 & 50 & 20 & 50 & 20 & 20 & $\begin{array}{ll}10 \\
10\end{array}$ & 20 & 30 & & & & & & & & & & & 20 & & 2 & & 2 & & $2^{2}$ & 2 & 60 & 50 & & & 20 & 10 & 4 & $\infty$ \\
\hline & 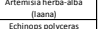 & & & & & & & ${ }^{10}$ & & & & & ${ }^{10}$ & ${ }^{30}$ & 30 & & 4 & & & & & & & & & & & & & & 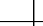 & & & & & ${ }_{10}$ & $2^{2}$ & $2^{2}$ & & ${ }_{10}^{10}$ & ${ }_{10}$ & & & & & & & & \\
\hline & 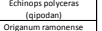 & & & 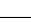 & & & & & & & & & 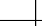 & 5 & 5 & 2 & 2 & 2 & & & & & & & & & & & & & & & & & & & & & & & & ${ }^{2}$ & 2 & & & & & & \\
\hline & $\mid$ & & 2 & 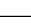 & $2^{2}$ & & & & & & & & & & 5 & - & 2 & - & $=$ & 2 & & - & & & & & & & & & & & & & & & & & & & & & & & & & & & - \\
\hline & 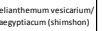 & & 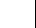 & & & & & & & & & & & & & ${ }^{2}$ & 5 & 2 & & & & 2 & & & & & & & & & & & & & & & & & & & & & & & & & & & \\
\hline 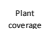 & 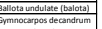 & & 20 & 40 & ${ }_{10}$ & & ${ }_{10}$ & & ${ }_{10}$ & & & ${ }_{10}$ & 30 & & & 20 & ${ }_{10}$ & 20 & ${ }_{10}$ & 10 & 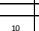 & ${ }_{10}$ & ${ }_{10}$ & & & 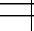 & & 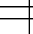 & & & & 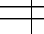 & & & & 2 & 2 & 5 & & 2 & 2 & ${ }_{10}$ & 10 & & & 30 & 25 & & 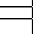 \\
\hline & 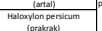 & & 而 & 2 & & & & & & & & & & & & & & & & 5 & & & & & & & & 3 & & & & 20 & 10 & & & 2 & & -1 & & 2 & & 5 & - & & & & & & \\
\hline & 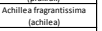 & & 20 & 2 & 20 & & & & 5 & & & & & & & 5 & 5 & 5 & 10 & 30 & 30 & 20 & 20 & & 5 & 10 & & & & & & & & 10 & & & & & & & & 5 & 20 & & & ${ }_{10}$ & 5 & ${ }_{10}$ & 20 \\
\hline & 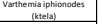 & & 4 & & 2 & & & & & & & & & & & & 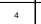 & & 5 & & & & & & & & & & & & & & & & & & & & & & & & & & & 2 & 2 & 2 & 2 \\
\hline & Piturante & & 2 & 2 & ${ }_{10}$ & & & & & & & & & & & & $\begin{array}{ll}10 \\
10\end{array}$ & & ${ }_{10}$ & 10 & & & & & & & & & & & & & & & & & & & & & & & & & & 2 & & & 2 \\
\hline & 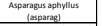 & & te & & & 5 & & & & & & & & & & & & & & & & & & & & & & & & & & & & & & & & & & & & 2 & & & & & & & \\
\hline & 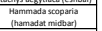 & & & & & ${ }_{10}^{10}$ & & ${ }_{30}$ & 10 & 10 & ${ }_{10}$ & 30 & & & & 5 & 20 & 5 & 3 & 10 & 10 & & & $\infty$ & 35 & 20 & & 95 & & & & & ${ }_{10}$ & 10 & & & & & & & & & & & & ${ }_{30}$ & $\infty$ & 80 & 20 \\
\hline & 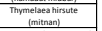 & & & & & & & & & & & & & & & & & & 2 & & & & & & & & & & & & & & & $2^{2}$ & & & & & & & & & & & & & & & \\
\hline & & & & & & & & & & & & & & & & & & & & & & & & & & & & & & & & & & & & & & & & & & & & & & & & & 4 \\
\hline
\end{tabular}


Map 1: Sede-Boqer Geobotanical runoff coefficient map, 1:50,000 scale

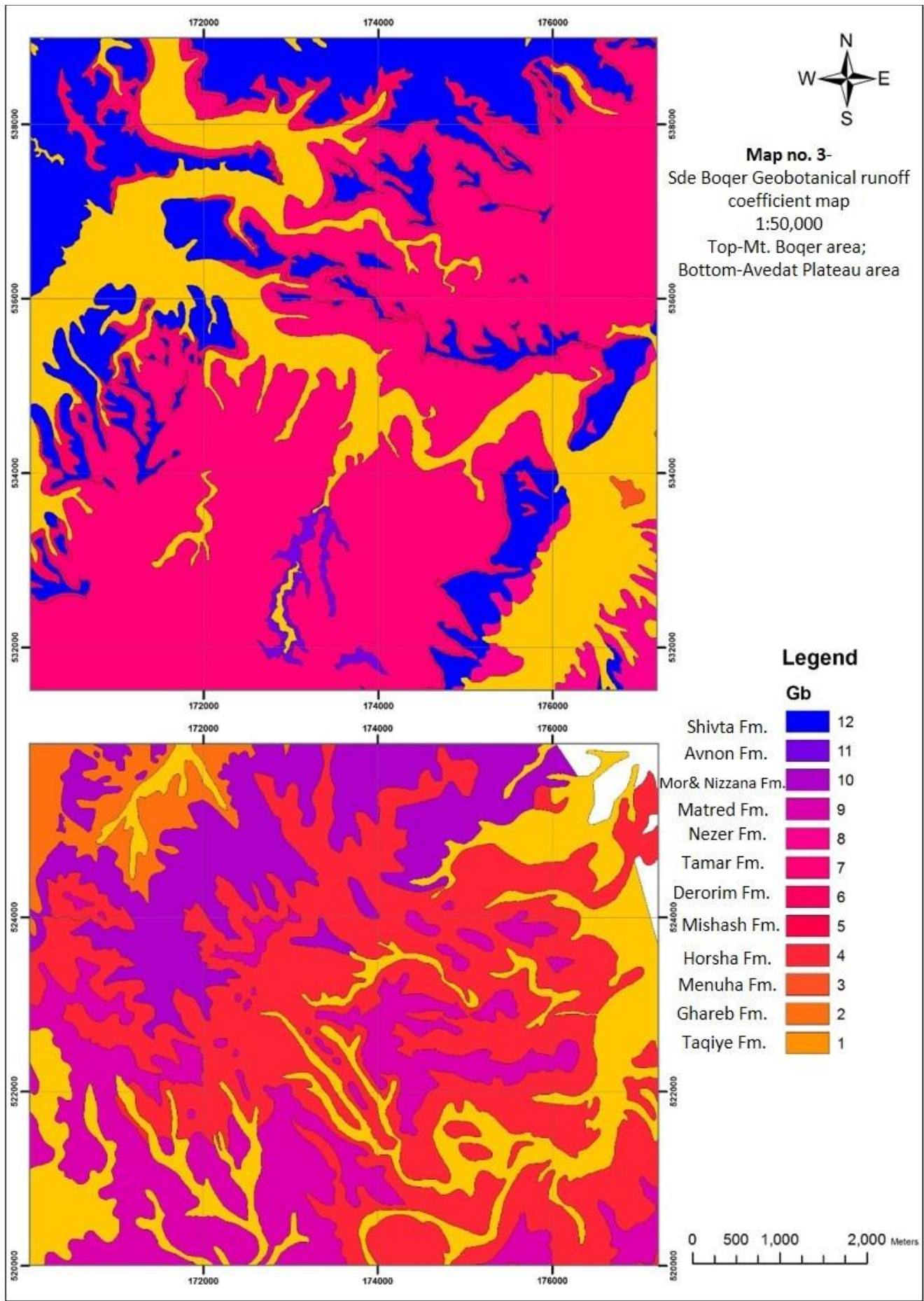




\section{Geo-archeological field survey}

A geo-archeological field survey was carried out in the study area to assess the distribution and characteristics of ancient agriculture installations described in the systematic archeology survey conducted by Cohen (1985). Sites located in rocky basins were selected from the whole list, excluding those farms and installations that were receiving flood water generated from large streams such as the Besor and Zin streams and were not directly supplied from local rocky resources. These ancient agriculture facilities (such as agricultural farms, sites of agricultural terraces and irrigation channels) were mapped on the GIS system and stored in a different layer for future consideration in comparison with the results of the present regional environmental framework.

\section{The GIS approach}

We used the same GIS technique presented in Wieler et al. (2016) to generate a geo-botanical runoff map 1:50,000 scale (map no.1), so it will compensate the geological map and geo-technical potential runoff map. As a next step, we merged the geo-botanical data with the geo-archeological data in order to generate a potential runoff map (map no.2).

Each of these thematic maps demonstrates the large variety of drainage basin sizes that include lithological changes along slopes. In order to overcome this complexity, the ARCGIS 9.3 software was selected as the analysis platform for the data sets in this research. It enables hydrological surface modeling, and thus generating stream networks and drainage basins. As for hydrological surface modeling, DEM analysis is a common tool (e.g., Ackermann et al., 2008). The potential contribution of rocky hillslope runoff yield is based on the assumption that water accumulates at the bottom of the slopes, and as the stream order increases, the runoff yield will increase accordingly. This assumption is only theoretical, when applying this method to the arid/semi-arid environment since, as stressed by Yair (1990), in most rain events there is no continuous flow along rocky slopes in arid environments. Yet, this assumption is crucial for the hydrological modeling when using the GIS tool. 
Journal of Landscape Ecology (2017), Vol: 10 / No. 3

Map 2: Sede-Boqer Potential runoff map, 1:50,000 scale

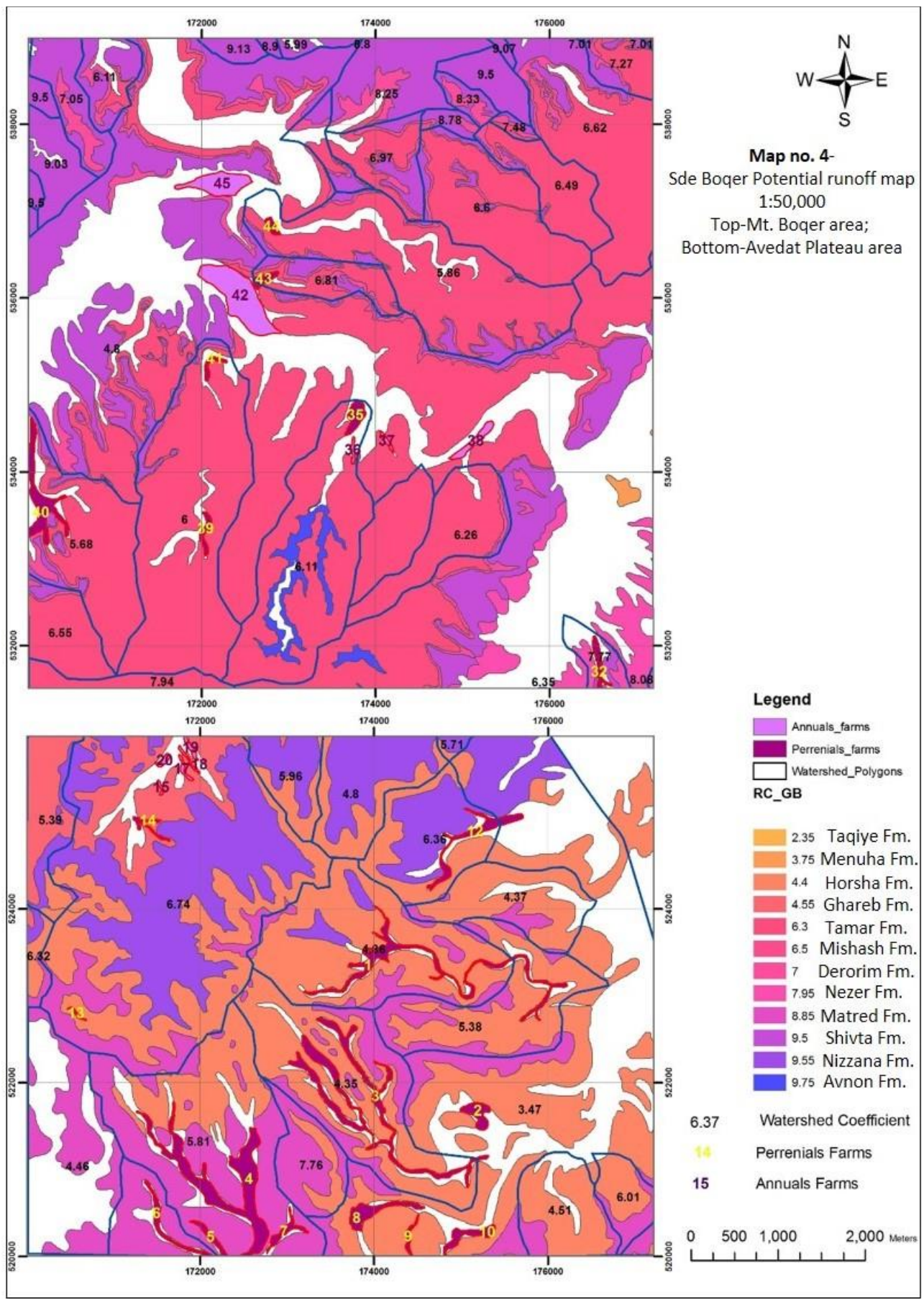


Wieler N., Avni Y., Rosensaft M., Olsvig-Whittaker L.: Variations in hillslope runoff as detected using geological strata coupled with vegetation patterns- implications on spatially distributed desert runoff agriculture

\section{RESULTS}

\section{Geological field survey}

The properties of the geological strata exposed in the research area are presented in Table 2. The distribution of these formations is presented in the geological map (1:50,000 scale) in Wieler et al. (2016).

\section{Geotechnical lab tests results}

According to the spray rain simulations and the physical parameter tests, runoff coefficients (RC) were calculated for the fourteen rock types as reported in Wieler et al. (2016). The results showed a clear gradient of the runoff yield from different lithologies ranging between $30-90 \%$ from the poorest (Taqiye Formation) to the richest (Nizzana Formation). The runoff coefficients presented were attributed to the spatial distribution of the geological formations presented in the geological map. The runoff coefficients are presented as geo-technical runoff map (1:50,000 scale) in Wieler et al. (2016).

\section{Vegetation patterns along arid rocky slopes}

Our methodology for testing vegetation patterns spatial distribution enabled us to correlate specific flora defined according to their chorotype (see table 3), to the subjected geological units (Fig. 5). We show that soft lithology formations are poor of vegetation coverage and are mainly characterized by Saharo-Arabian chorotype vegetation, whereas, the dense lithologies are rich with vegetation and characterized by diverse chorotypes (i.e., Irano-Turanian, Saharo-Arabian and Mediterranean). Mesophilic vegetation (e.g., Varthemia iphionodes, Ballota undulate, Geofit) are limited to soil pockets located along dense and continuous rock surfaces, such as the Shivta and Avnon Formations. Other Mediterranean chorotype vegetation (e.g., Thymelaea hirsute, Asparagus aphyllus, Drimia maritima) were mainly located along colluvial units that are located beneath Nezer, Shivta and Avnon Formations.

Colluvial units and rock surfaces also host Irano-Turanian chorotype vegetation (e.g., Achillea fragrantissima, Helianthemum vesicarium, Echinops polyceras, Artemisia herba-alba). While the dense lithology formations host diverse chorotype vegetation, the soft lithology formations hosts mainly Saharo-Arabian vegetation (e.g., Hammada salicornica, Reaumuria hirtella, Astragalus spinosus, Zilla spinose, Stachys aegytiaca). The Saharo-Arabian Zygophyllum dumosum, is an exception since it is present along both soft and dense lithologies. Its' presence indicate on the total percolation of the precipitation with almost no runoff contribution. These distinct differences between the different lithologies resulting from the diverse environmental parameters (e.g., rock type, soil rock ratio, soil depth, stone coverage, slope length, slope aspect, slope inclination, salinity) involved; thus shaping the sediment and water fluxes along each slope. We found that the soil rock ratio act as key parameter in order to define the vegetation patterns; thus, act as a good runoff estimating tool (Fig. 6). 
Fig. 5: Redundancy analysis (RDA) graph experiencing different geological formations and different plant species. Plant species marked in red arrows, geological formations marked in green arrows. Abbreviations of environmental parameters (green arrows): shivtaco- Colluvial parts of Shivta formation; shivtacl-Cliff parts of Shivta formation; menuhami- Menuha formation covered with Mishash chert fragments; gharebni- Ghareb formation covered by Nizzana debris; taqiani- taqiye formation covered by Nizzana debris; horshma- horsha formation covered by Matred debris.

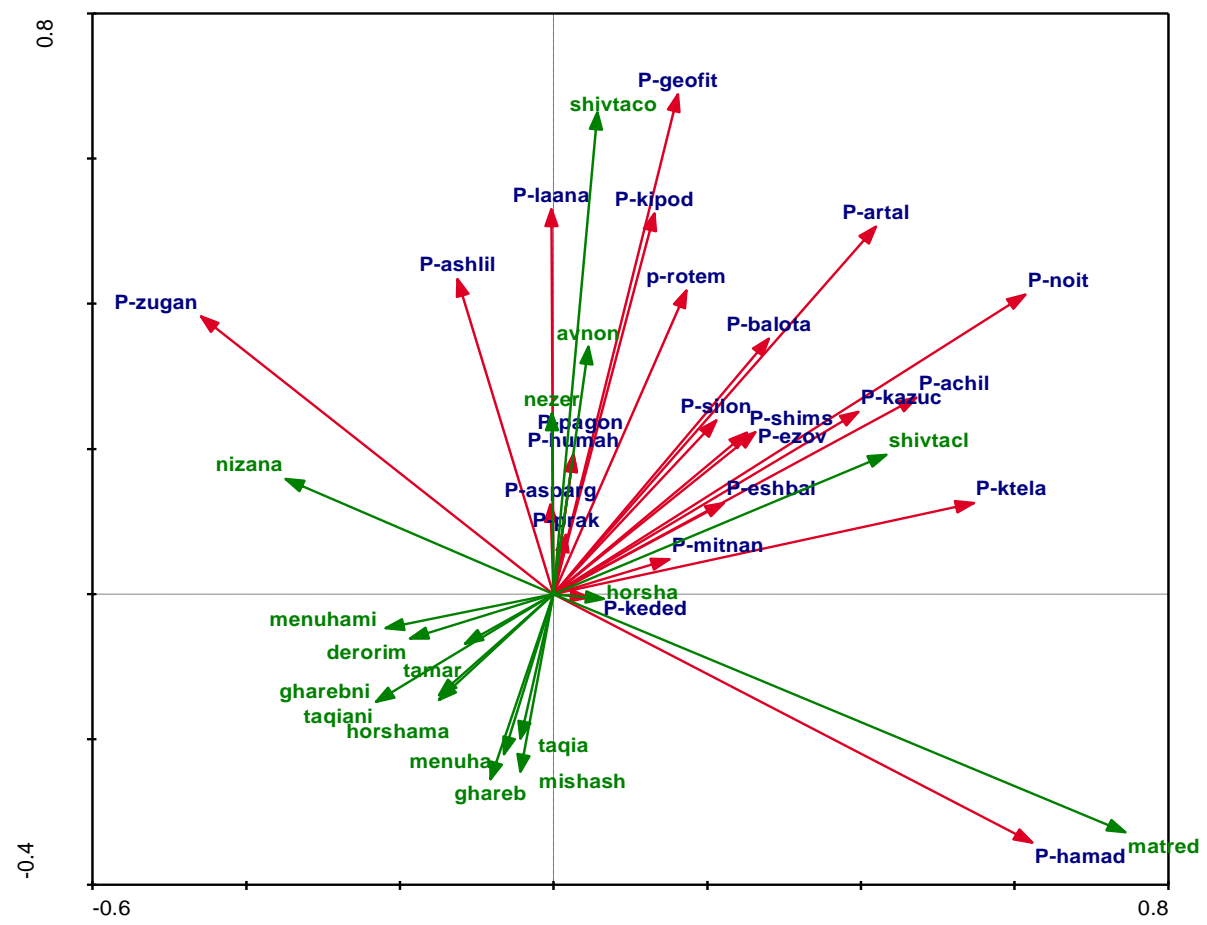

Fig. 6: Testing the relationship between soil rock ratio and vegetation coverage in the subjected area, show that soil rock ratio is a reliable marker for perennial vegetation coverage

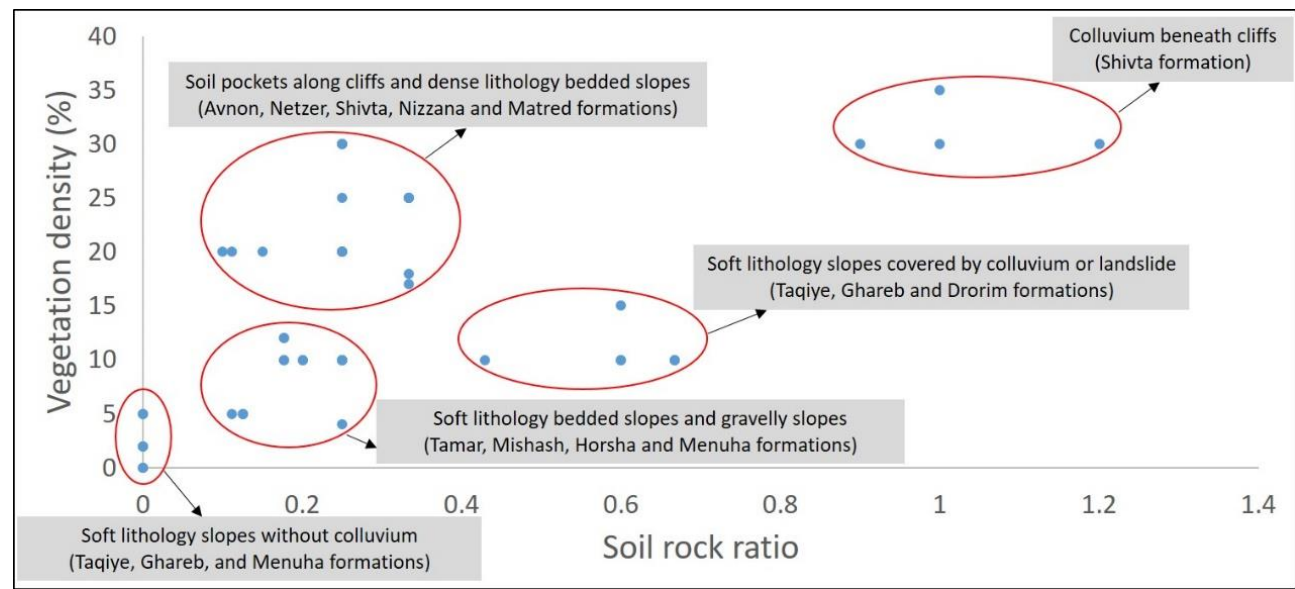


Wieler N., Avni Y., Rosensaft M., Olsvig-Whittaker L.: Variations in hillslope runoff as detected using geological strata coupled with vegetation patterns- implications on spatially distributed desert runoff agriculture

Detailed characterization of the cluster analysis presented in Fig. 6 along with Yair \& Shachak (1982) and Olswig-Whittaker et al. (1983) methods enabled us to generate five representative eco-hydrologic units (Table 5). It can be seen according to these units that slope inclination coupled with slope length and soil depth play a major role on the vegetation patterns rather than slope aspect. Moreover, a possible explanation for the presence of only Saharo-Arabian chorotype vegetation along the soft lithology formations can be attribute to the higher salinity found upon them. Likewise, it is important to mention that many local-scale factors that were not effectively captured with our data could be responsible for generating some of the observed biogeographic patterns.

Table 5: Description of the five major eco-hydrologic units

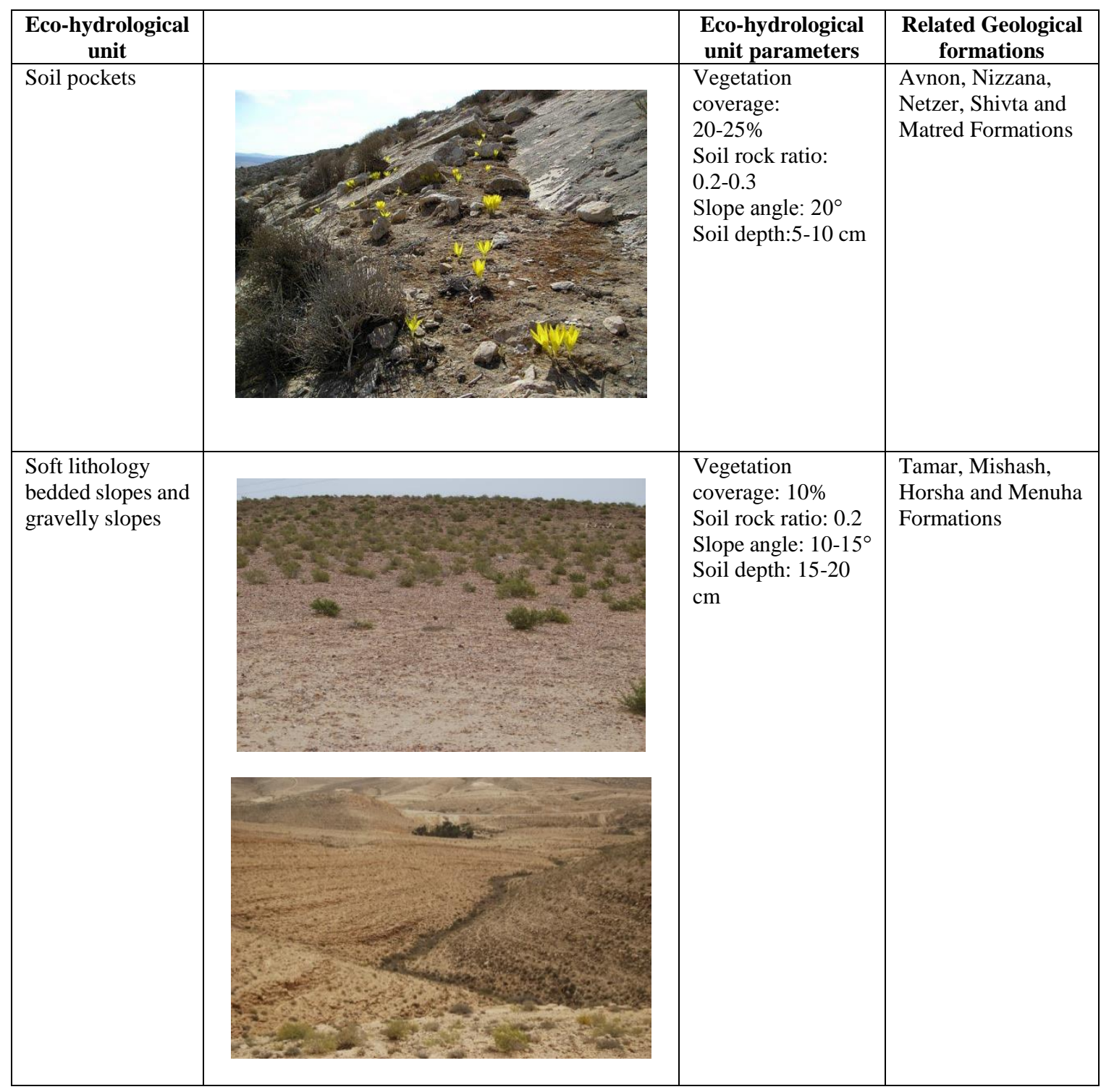




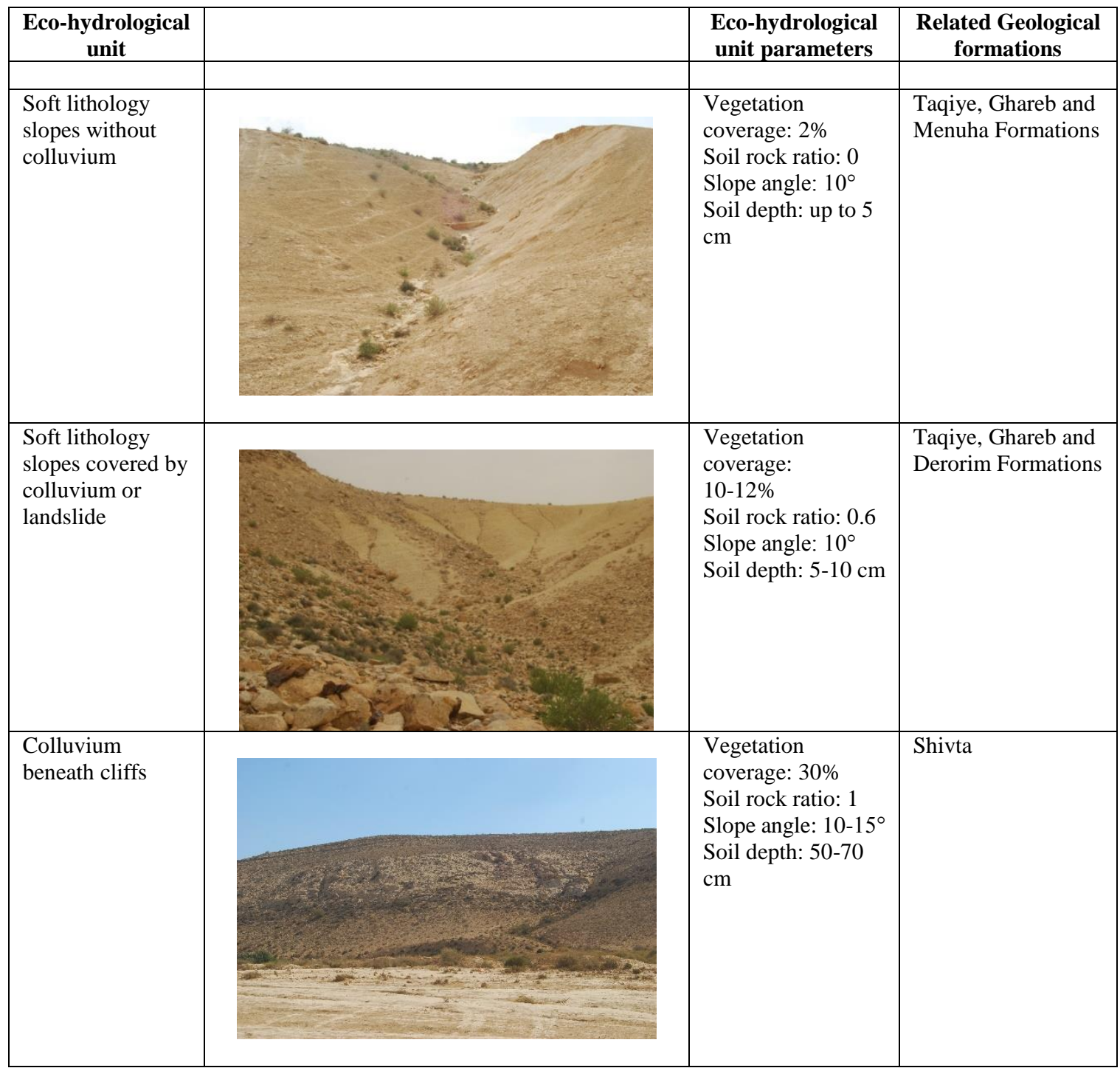

For testing large scale spatial distribution our last step was generating a geo-botanical runoff coefficients map (see map no.1)by using the GIS spatial analysis tool in order to transform the geo-botanical data (i.e., termed as $\mathrm{Gb}$ in map no. 1) to a semi-quantitative runoff coefficient scale, ranging between 1 and 12. In this scale 1 represent the poorest runoff coefficient and 12 represent the best runoff coefficient. The runoff scale arranged from high to poor runoff units as follows: Shivta Fm. (12)- Avnon Fm.(11) - Nizzana and Mor Fm.(10) - Matred Fm.(9) - Nezer Fm. (8) - Tamar Fm. (7)- Derorim Fm. (6) - Mishash Fm. (5) Horsha Fm. (4) - Menuha Fm. (3) - Ghareb Fm. (2) - Taqiye Fm. (1).

Projecting the ancient agriculture sites on the geo-botanical runoff potential map (map no.1) along with the previous runoff maps discussed in Wieler et al. (2016) yielded a synthetic large scale runoff map (map no. 2). The data in this map combines the geo-botanical scale $(\mathrm{Gb})$ and the runoff coefficient scale $(\mathrm{Rc})$, to form a new scale termed as 
Wieler N., Avni Y., Rosensaft M., Olsvig-Whittaker L.: Variations in hillslope runoff as detected using geological strata coupled with vegetation patterns- implications on spatially distributed desert runoff agriculture

RC_GB in map no. 2. In this scale, the value 2.35 represent the poorest runoff coefficient and 9.75 represent the best runoff coefficient. The values are color coded, the poorest values are orange colored and high values are purple to blue colored.

\section{DISCUSSION}

The type and distribution of perennial plants along bedrock outcrops were used in this study as an important tool for forecasting the long-term bedrock runoff generation yield in an arid environment. Thus, we found that coupling geological strata and vegetation patterns constitute a reliable marker for testing spatial variation of desert runoff agriculture. This methodology compensate the previous runoff scale results suggested in Wieler et al. (2016). The integration of geothecnical laboratory experiments, field observations and the geo-botanical parameters allows better understanding of the water transmission and connectivity in desert environment. Along with previous studies (Yair et al., 1978; Yair \& De Ploey, 1979; Lavee \& Yair, 1980; Yair, 1983; Kuhn \& Yair, 2004) we found that the water transmission of a specific geological unit depends on the following factors: 1. Rock type 2. Spatial distribution of flat rocky surface 3. Connectivity between these rocky flat surfaces along the slope 4 . Number and size of cliffs characterizing the unit 5. Streams proximity. 6. Rock debris size on the slope and the percentage of the slope covered by them. 7. Slope length. Spatial analysis of the vegetation cover (map no. 1) shows clear correlation to downslope runoff transmission. As the slope gets longer, it has higher number of hydraulic barriers which effect directly the amount and variety of the vegetation cover.

Due to the sensitivity of perennial vegetation patterns to water availability in arid rocky terrains, they emphasize the ability of compensating the harsh conditions by selecting their growing habitat. Hence, specific flora can be found under specific geological formations that increases the runoff. Therefore, the lithologic composition was found to be the most important environmental factor controlling the distribution of plants in the area. It can clearly be seen in Figure 5, that perennial vegetation with Mediterranean chorotypes correlates with geological units generating high runoff yield, mainly composed of dense limestone and dolomite (i.e. Shivta, Nizzana, Matred and Avnon formations). On the contrary, Zygophyllum dumosum, which has a Saharo-Arabian chorotype, is an indicative flora for arid environments, and therefore, it is widely spread and can be detected both at high and low runoff generating geological units. In addition, stone coverage along the rocky slopes was found to be an impact factor regarding its ability to generate or to cause a delay in runoff generation (Lavee \& Poesen, 1993). Along with these findings, the higher variety of botanical species concentrates along median size rock fragments. Interestingly, the spatial distribution of flat rocky surfaces which characterize some formations manage to compensate the existence of highly absorbing formations that are located downslope. As a result, higher vegetation coverage is located beneath them. Such is the case of the Shivta formation (composed of massive unbedded dense limestone), which acts as a high runoff producer. The high amount of runoff generated by this formation manages to cross the chalky-marly Derorim Formation located downslope and reach the valley bottom. This is done by the concentration of the runoff in ravines and first order streams connecting the high slopes with the valleys by short and steep channels. A similar situation exists within the Nizzana Formation, whereby the Nizzana Formation that has a high runoff coefficient, slides on the clayey and marly section of the Taqiye and Ghareb formations, getting close to the valley bottom. When these rock surfaces are located close to the valleys they act as preferred runoff channel, thus increasing vegetation coverage. 
Environmental implications: compiling the results of the botanical survey, runoff units and the Archeological record in the Negev Highlands

As previously described, a systematic archeological survey conducted by Cohen (1985) yielded forty-five agricultural installations located within the study area; all sites are from the Byzantine - Early Muslim period.

Based on map no. 2 we found correlation ratio of $80 \%$ between the location of the archeological agricultural installations and the drainage basins composed of geological units producing high runoff expressed by higher runoff coefficients (i.e., Shivta, Nizzana, Matred and Avnon formations). The correlation is based on thirty-six out of forty-five installations that were located downslope high runoff units. Interestingly, there were only two agricultural installations at the bottom of the Tamar formation slopes, even though it comprises a large portion (19\%) of the study area. Low density distribution of agricultural installations was found at the bottom of the chalky-marly "soft" formations (Derorim, Ghareb, Taqiye, Mor, Menuha and Horsha formations) (map no. 2).

These findings imply on the ability of vegetation patterns to forecast preferred geological runoff units, thus to stress the importance of the geological substrate in affecting the locations of agricultural installations. Carefully designed agricultural plots, probably allocated for perennial crops (Fig. 2) were located under high runoff yield formations, whereas in most of the other rocky slopes, less intensive installations were constructed designed mainly for annual crops (Fig. 3). The fact that most of the agricultural installations are restricted to the location of the present best runoff generation units may suggest that there was no significant change in the environmental conditions observed since these installations were built, some 1600 years ago. Recent study (Ashkenazi et al., 2014) indicates that after the $10^{\text {th }}$ century, the semi-nomad Bedouin population almost constantly practiced desert agriculture on a local scale in the Negev Highlands. This indicates that todays' desert climate and environment are suitable for desert agriculture practices, and that the desert environment in the southern Levant was almost unchanged at least during the last two millennia.

\section{CONCLUSIONS}

Integrating vegetation patterns, geological substrate data and bedrock-runoff generation data on a GIS model on a large scale $\left(160 \mathrm{~km}^{2}\right)$ of the Negev Highlands yields a synthetic runoff potential map. This map is a unique new product made for the first time during this study. Basing on it, runoff yield can be predicted for different scales, ranging from that of a single lithology slope to that of a basin of varying lithologies. Although the map was developed for the Negev Highlands desert, the GIS model could be applicable to other arid and semi-arid regions worldwide.

Our present findings reinforce and compensate the findings presented in Wieler et al. (2016) for testing the correlation between the present drainage basin runoff potential and the locations of the Byzantine - Early Muslim runoff-farms (forty-five sites). Most of the archeological agriculture installations are restricted to slopes and drainage basins that produce a greater amount of runoff at present, and almost none of them are located within drainage basins that produce low runoff. This correlation indicates that slope runoff generated from the geological substrate played a substantial role in decisions made by the ancient farmers regarding the site locations of the agriculture farms. As the reconstructed properties of these sites functioned very similar to the way they work at present, we conclude that the past desert conditions were fundamentally similar to those that exist in the region today. Therefore, we further conclude that the rock-rain-runoff relations in the Negev Highlands today imply there was neither an environmental change nor a significant climate 
Wieler N., Avni Y., Rosensaft M., Olsvig-Whittaker L.: Variations in hillslope runoff as detected using geological strata coupled with vegetation patterns- implications on spatially distributed desert runoff agriculture

change in the past 1600 years and that this is probably true for other desert regions in the Middle East as well.

\section{REFERENCES}

Ackermann, O., Svoray T., Haiman, M., (2008). Nari (calcrete) outcrop contribution to ancient agricultural terraces in the Southern Shephelah, Israel: insights from digital terrain analysis and a geoarcheological field survey. Journal of Archeological Sciences, 35, 930-941.

Ackermann, O., Zhevelev, H. M., and Svoray, T., (2013). Sarcopoterium spinosum from mosaic structure to matrix structure: Impact of calcrete (Nari) on vegetation in a Mediterranean semi-arid landscape. Catena, 101, 79-91.

Amundson, R., Heimsath, A., Owen, J., Yoo, K., and Dietrich, W., (2015). Hillslope soils and vegetation. Geomorphology 234, 122-132.

Arkin Y., Braun M., (1965). Type sections of upper Cretaceous formations in the northern Negev (southern Israel). Israel Geological Survey, Stratigraphic sections 2a. 19 p.

Ashkenazi, E., Avni, Y., Avni, G., (2012). A comprehensive characterization of ancient desert agricultural systems in the Negev Highlands of Israel. Journal of Arid Environments, $86,55-54$.

Ashkenazi, E., Chen, Y., Avni, Y., Lavee, S., (2014). Fruit trees' survival ability in an arid desert environment without irrigation in the Negev Highlands of Southern Israel. Israel Journal of Plant Sciences, 62, 5-16.

Avni, G., (2014). The Byzantine Islamic Transition in Palestine - An Archaeological Perspective. Oxford: Oxford University Press.

Avni, G., Porat, N., Avni, Y., (2013). New dating of the ancient agriculture systems in the Levant. Journal of Field Archeology, 38, 332-346.

Avni, Y., Porat, N., Avni G., (2012). Pre-farming environment and OSL chronology in the Negev Highlands, Israel. Journal of Arid Environments, 86, 12-27.

Braak, C.J.F.ter, Prentice, I.C., (1988). A theory of gradient analysis. Advances in ecological research, 18: 271-317.

Braak, C.J. F. ter, Smilauer, P., (2002). CANOCO Reference Manual and CanoDraw for Windows User's Guide: Software for Canonical Community Ordination (version 4.5).

Braun, M., Arkin, Y.,(1965). Type sections of upper Cretaceous formations in the northern Negev (southern Israel). Geological Survey of Israel, Stratigraphic Team, Sections 2a, 18p.

Bruins H. J., (2012). Ancient desert agriculture in the Negev and climate-zone boundary changes during average, wet and drought years. Journal of Arid Environments 86, 28-42.

Bruins H. J., Ore G., (2009). Runoff from loess or bedrock? Hillslope geoarcheology of ancient runoff farming systems at Horvat Haluqim and Har Eldad in the central Negev Desert. Israel Journal of Earth Sciences 57, 3-4, 85-114.

Cohen, R., (1985). Israel archeological field survey- Sede Boqer west sheet (167). Israel Antiquities Authority, Jerusalem, Israel (in Hebrew).

Dan, J., Yaalon, D.H., Koyumdjisky, H., Raz, Z., (1972). The soil association map of Israel. Israel Journal of Earth Sciences 21, 29-49.

Danin, A., (1983). Desert vegetation of Israel and Sinai. Jerusalem: Cana Publishing House 
$148 \mathrm{p}$.

Droppelman, K.J., Ephrath, J.E., Lehmann, J., Berliner P.R. (2000).Water use efficiency and uptake patterns in a runoff agroforestry system in an arid environment. Agroforestry Systems 49, 223-243.

Evenari, M., Shanan, L., Tadmor, N., (1982). The Negev - The Challenge of the Desert. Cambridge, Mass. Harvard University Press.

Gerard, F., Blank, L., Bunce, R.G.H., Carmel, Y., Caudullo, G., Clerici, N, Deshayes, M., Erikstad, L., Estreguil, C., Framstad, E., Granholm, A-H., Halabuk, A., Halada, L., Harari-Kremer, R., Hazeu, G.W., Hennekens, S.M., Holmgren, J., Kikas, T., Kuusemets, V., Lang, M., Levin, N., Luck-Vogel, M., Morton, D., Mucher, C.A., Nilsson, M., Nordkvist, K., Olsson, H., Olsvig-Whittaker, L., Raet, J., Roberts, W., Roerink, G.J., Sepp, K., Scholefield, P.A., Vain, A., Van Calster, H., Weissteiner, C.J., (2012). Assessing the role of EO in biodiversity monitoring: options for integrating in-situ observations with EO within the context of the EBONE concept.

Hikel, H., Yair, A., Schwanghart, W., Hoffmann, U., Straehl, S., and Kuhn, N., (2012). Experimental investigation of soil ecohydrology on rocky desert slopes in the Negev Highlands, Israel. Zeitschrift fur Geomorphologie 57, 39-58.

Huntington, E., (1911). Palestine and Its Transformation. New York, 403 p.

Issar, A.S., Zohar, M., (2004). Climate Change - Environmental and Civilization in the Middle East. Springer, 252 p.

Kuhn, N.K., Yair, A., (2004). Spatial distribution of surface conditions and runoff generation in small arid watersheds, Zin Valley Badlands, Israel. Geomorphology 57, 183-200.

Lavee, H., Poesen, J., (1993). Stone coverage impact on runoff generation. Israel Geography Researches, 13,132-148 (in Hebrew).

Lavee, H., Poesen, J., Yair, A., (1997). Evidence of high efficiency water harvesting by ancient farmers in the Negev Desert, Israel. Journal of Arid Environments 35, 341-348.

Lavee, H., Yair, A., (1980). Storm runoff in humid and arid areas: testing Horton's model. Israel Geography Researches, 11, 15-27 (in Hebrew).

Lep, J., Smilauer, P., (2003). Multivariate analysis of ecological data using CANOCO. Cambridge Univ. Press.

Liphschitz, N., (1996). The vegetational landscape of the Negev during antiquity as evident from archaeological wood remains. Israel Journal of Plant Sciences Vol. 44, no. 2-3, pp. 161-179.

Nevo, Y. D., (1991). Pagans and Herders, A Re-examination of the Negev Runoff Cultivation Systems in the Byzantine and Early Arab Periods, Achva Press, Jerusalem.

Olswig-Whittaker, L., Shachak, M., Yair, A, (1983). Vegetation patterns related to environmental factors in a Negev Desert watershed. Vegetatio 54, 153-165.

Orland, I.J., Bar-Matthews, M., Kita, N.T., Ayalon, A., Matthews, A., Valley, J.W., (2009). Climate deterioration in the Eastern Mediterranean as revealed by ion microprobe analysis of a speleothem that grew from 2.2 to $0.9 \mathrm{ka}$ in Soreq Cave, Israel. Quaternary Research 71, 27-35.

Shanan, L., Tadmor, N., Evenari, M., (1963). Ancient agriculture in the southern Negev VII. Runoff generation in large drainage basins. Ketavim, 12, 125-144 (in Hebrew).

Shor, Y., (1987). Water accumulation along the Derorim Formatiom (Turonian age) at Sede-Boqer area, northern Negev. M.Sc. thesis, Hebrew University, Jerusalem, Israel (in 
Hebrew, English abstract).

Tadmor, N., Shanan, L., Evenari, M., (1961). Ancient agriculture in the southern Negev. Correlating between drainage basin and cultivated area. Ketavim, 11, $69-78$ (in Hebrew).

UNESCO, (1979). Map of the world distribution of arid regions-explanatory note. Man and Biosphere (MAB) Technical Notes no. 7. UNESCO, Paris.

Vaks, A., Bar-Matthews, M., Matthews, A., Ayalon, A., Frumkin, A., (2010). Middle-Late Quaternary paleoclimate of northern margins of the Saharan-Arabian Desert: reconstruction from speleothems of Negev Desert, Israel. Quaternary Science Reviews 29, 19-20, 26472662.

Wieler, N., Avni, Y., Rosensaft, M., (2016). The significance of the geological strata on desert runoff agriculture: indications for stable desert environment over the last 1600 years in southern Israel. Journal of Arid Environments 135, 147-163.

Yaalon, D.H., Dan, J., (1974). Accumulation and distribution of loess-derived deposits in the semi-desert and desert fringe of Israel. Zeitschrift fur Geomorphologie, 20, 91-105.

Yair, A., (1983). Hillslope hydrology water harvesting and areal distribution of some ancient agriculture systems in the northern Negev desert. Journal of Arid Environments 6, 283-301.

Yair, A., (1987). Environmental effects of loess penetration into the northern Negev Desert. Journal of Arid Environments, 13, 9-24.

Yair, A., Danin, A., (1980). Spatial variations in vegetation as related to the soil moisture regime over an arid limestone hillside, northern Negev, Israel. Oecologia 47, 83-88.

Yair, A., Klein, M., (1973). The influence of surface properties on flow and erosion processes on debris covered slopes in an arid area. Catena 1, 1-18.

Yair, A., Lavee, H., (1974). Areal contribution to runoff on scree slopes in an extreme arid environment- a simulated rainstorm experiment. Zeitschrift fur Geomorphologie. N.F. 21, 106-121.

Yair, A., De Ploey, J., (1979). Field observations and laboratory experiments concening the creep process of rock blocks in an arid environment. Catena 6, 245-258.

Yair, A., Shachak, M. (1982). A case study of energy, water and soil flow chains in an arid ecosystem. Oecologia, 54(3), 389-397.

Yair, A., Raz-Yassif, N., (2004). Hydrological processes in a small arid catchment: scale effects of rainfall and slope effects. Geomorphology 61, 155-169.

Yair, A., Sharon, D., Lavee, H., (1978). An instrumented watershed for the study of partial area contribution of runoff in the arid zone. Zeitschrift fur Geomorphologie. N.F. 29, 71-82 